\title{
The Development of Accrual Accounting in Indonesia
}

\author{
Eliana $^{1}$, Nurhayati ${ }^{1}$, Ferdi Nazirun Sijabat ${ }^{2}$, Supriyanto $^{3}$, Banta Karollah ${ }^{2}$ \\ \{eliana@stiesabang.ac.id\} \\ ${ }^{1}$ Department of Accounting, Sekolah Tinggi Ilmu Ekonomi Sabang, Banda Aceh, Indonesia \\ ${ }^{2}$ Department of Management, Sekolah Tinggi Ilmu Ekonomi Sabang, Banda Aceh, Indonesia \\ ${ }^{3}$ Department of Business Administration, Politeknik LP3I Medan, Medan, Indonesia
}

\begin{abstract}
This study aims to describe the research on the development of accrual accounting in Indonesia. This study analyzed 10-accreditation-journal in Indonesia from 2010-2017. There are 25 articles that discuss accrual accounting in Indonesia. The researcher classified these articles based on the topic, research method, model used, and the research result articles in Indonesia. The articles obtained mostly were published in the Accounting and Business Journal. The most frequent antecedent topic were studied by researcher comprise of application, determinant or factors, implementation, model, role and reliability. Meanwhile for the most frequent topics of the consequences were comprise of three articles over the quality of financial statements and accrual-based accounting standards. Overall, this study uses a survey method. This study is expected to contribute in three folds: Firstly to provide evidence about the development of accrual accounting report after the issuance of Law No. 71/2010. Secondly, it can help further researchers to formulate problems that occur in regional government regarding the development of accrual accounting. Additionally, it provides information about the extent to which the application of accrual accounting has been implemented in Indonesia. Therefore this information can practically be useful for regional governments throughout Indonesia.
\end{abstract}

Keyword : Accounting, Business Journal.

\section{Introduction}

Accrual basis accounting is a basis for accounting where economic transactions and other events are recognized, recorded and presented in the financial statements when the transaction occurs without regard to when income or expenses are received or paid. In accrual basis, accounting records assume that the transaction is recognized because the agency concerned has rights or obligations when the transaction is recorded. Therefore recognition of income/costs in the application of accrual basis accounting is contrary to the application of cash basis accounting.

Despite Law No. 71 of 2010 was issued and clearly regulate the obligatory for the government to comply with the accrual system in delivering their financial activities. However, in reality, many local and regional governments have not been able to switch to accrual basis or still not ready to comply to this regulation due to a few common reasons such as lack of commitment, level of education, less capacity of staff, information technology, and so forth. This situation appears as common in all regional and local government in Indonesia, where the degree of accrual implementation is still low. 
This research refers to research conducted by [1] who examined the development of earnings management in Indonesia during 1999-2016. This study tries to review how the development of accrual accounting in Indonesia by considering the following factors like commitment, leadership style, resources, organizational structure, communication, and staff training. It is viewed that the factors motivate local governments to implement accrual accounting all over Indonesia. This study uses 25 articles on accrual accounting both in the regional government in Indonesia in 10-accredited-journal and 7 journals which is indexed by Google Scholar. This study attempts to review the development of accrual accounting in Indonesia from 2010 to 2018. Besides, the study was also conducted to comprehend the direction of accrual accounting development in Indonesia. Therefore, it is expected to contribute to three folds: In the first place, providing evidence about the development of accrual accounting report after the issuance of Law No. 71 the Year 2010. Secondly, assist to build a foundation for future research in formulating problems that occur in the regional government efforts towards accrual accounting. Thirdly, providing information about the extent to which the implementation of accrual accounting has been carried out in Indonesia. Thus it is expected that this contribution can be useful for regional governments throughout Indonesia. The method used in this study is the "charting the field"[2]. It is known as the method used to identify articles according to the object to be studied, then to classify articles according to the object under study. Afterward, it is also applicable in classifying the articles based on topics and methods. This method enables authors or researchers to classify articles easily. As the result, the authors can develop a clear understanding about the topic under study, as found in [2] study which divided into two periods to indicate changes in the development of research from time to time with results that still use a limited percentage.

This study was conducted in the following phases: In the first phase, this study identified 2010 articles up to now about 10 accredited journals about the development of accrual accounting both in the company and the local government. article selection is based on accredited journals because the quality of the journal meets the requirements or adequate standardization of the Republic of Indonesia Ministry of Research, Technology, and Higher Education, and also has passed a fairly rigorous editing process such as: free from plagiarism, the journals can be accessed through online. Third, the selection of the article is mainly related to the development of the implementation of accrual accounting in Indonesia by typing "accrual" keywords in their respective journal websites' search menu.

The following table enlists all journals, institution (publisher of the journals), authors, titles and citation record. The journals which included in this study are mostly published by Indonesia Higher Education Institution both public and private university, but Human Resources Develoment Agency/Badan Pengembangan Sumber Daya Manusia (BPSDM) Banten is an only government agency that publishes the journal which is included in this study.

Table 1. List of Accredited Journals

\begin{tabular}{ll}
\hline \multicolumn{1}{c}{ Journal } & \multicolumn{1}{c}{ Publishers } \\
\hline Jurnal Akuntansi dan Investasi (JAI) & Universitas Muhammadiyah Yogyakarta \\
Jurnal Media Riset Akuntansi, Auditing \& Informasi & Lembaga Penerbit Fakultas Ekonomi dan Bisnis \\
Jurnal Akuntansi dan Keuangan(JAK) & Petra Christian University \\
Jurnal Akuntansi Multiparadigma (JAM) & Universitas Brawijaya \\
Jurnal Akuntansi \& Bisnis (JAB) & Universitas Negeri Sebelas Maret \\
Jurnal Dinamika Akuntansi (JDA) & Universitas Negeri Malang \\
Jurnal Ilmiah Akuntansi \& Bisnis (JIAB) & Universitas Udayana \\
\hline
\end{tabular}




\begin{tabular}{ll}
\hline \multicolumn{1}{c}{ Journal } & \multicolumn{1}{c}{ Publishers } \\
\hline Jurnal Ekonomi Manajemen Akuntansi (JEMA) & STIE Darmaputra Semarang \\
Jurnal Ilmiah Mahasiswa Akuntansi (JIMAT) & Universitas Pendidikan Ganesha \\
Jurnal Akuntansi (JA) & Universitas Islam Negeri Malang \\
Jurnal Ilmu Akuntansi (JIA) & Universitas Islam Negeri Jakarta \\
Jurnal Ekonomi Manajemen Bisnis dan Akuntansi & Universitas SAM Ratulangi Manado \\
(JEMBA) & \\
Jurnal Ekonomi Akuntansi \& Manajemen (JEAM) & Universitas Jember \\
Jurnal Lingkar Widyaswara (JILIWI) & BPSDM Banten \\
Jurnal Online Mahasiswa JOM) & Universitas Riau \\
Jurnal Akuntansi \& Auditing (JAA) & Universitas Diponegoro \\
Jurna Ekonomi \& Bisnis (JEBI) & Universitas Atma Jaya Yogyakarta \\
\hline
\end{tabular}

Furthermore, table 2 indicates that from 2010 to 2018, JAI is considered as the most dominant journal which publishes the article under accrual accounting topic. It was recorded to have published around $14 \%$ out of all articles. Meanwhile, the others are $7 \%$ which consists of JAK, JAM, JDA, JIAB, JAUNEJ. Likewise for JMRAAI, JAB, DE, JIMAT, JA, JIA, JILIWI, JIIS, JAA, JEBI articles with a share of $3 \%$. The table also pinpoints the increase of the number of the published article under accrual accounting topic during two periods (20102014 and 2015-2018) around 16\%, which rose from 9 articles to 16 articles. However, the increase in the number of published articles was fluctuating.

Table 2. Sample Distribution

\begin{tabular}{|c|c|c|c|c|c|c|}
\hline \multirow[t]{2}{*}{ Journal } & \multicolumn{2}{|c|}{$2010-2018$} & \multicolumn{2}{|c|}{$2010-2014$} & \multicolumn{2}{|c|}{$2015-2018$} \\
\hline & No & Percentage & No & Percentage & No & Percentage \\
\hline JAI & 3 & 0.14 & 0 & 0 & 3 & 0.14 \\
\hline JMRAAI & 1 & 0.03 & 0 & 0 & 1 & 0.03 \\
\hline JAK & 2 & 0.07 & 1 & 0.03 & 1 & 0.03 \\
\hline JAM & 2 & 0.07 & 1 & 0.03 & 1 & 0.03 \\
\hline $\mathrm{JAB}$ & 1 & 0.03 & 1 & 0.03 & 0 & 0 \\
\hline JDA & 2 & 0.07 & 0 & 0 & 2 & 0.07 \\
\hline JIAB & 2 & 0.07 & 0 & 0 & 2 & 0.07 \\
\hline DE & 1 & 0.03 & 1 & 0.03 & 0 & 0 \\
\hline JIMAT & 1 & 0.03 & 0 & 0 & 1 & 0.03 \\
\hline JA & 1 & 0.03 & 1 & 0.03 & 0 & 0 \\
\hline JIA & 1 & 0.03 & 0 & 0 & 1 & 0.03 \\
\hline JEMBA & 2 & 0.07 & 0 & 0 & 2 & 0.07 \\
\hline JAUNEJ & 2 & 0.07 & 2 & 0.07 & 0 & 0 \\
\hline JILIWI & 1 & 0.03 & 0 & 0 & 1 & 0.03 \\
\hline JIIS & 1 & 0.03 & 0 & 0 & 1 & 0.03 \\
\hline JAA & 1 & 0.03 & 1 & 0.03 & 0 & 0 \\
\hline JEBI & 1 & 0.03 & 1 & 0.03 & 0 & 0 \\
\hline Total & 25 & & 9 & & 16 & \\
\hline
\end{tabular}

\section{Research Method}

This research adopted "charting the field", methode developed by Hesford et al., work by classifying each article based on the topic and research method [2]. The classification of 
articles on the development of accrual accounting, when viewed from research topics, is divided into two namely antecedents (factors that motivate the development of accrual accounting) and their consequences (the impact of the development of accrual accounting). Table 4 shows the classification of articles on accrual development in Indonesia by topic. As previously explained, the topics discussed are classified into two periods. From the table, it is concluded that during 8 years, the preliminary topic of accrual accounting development was around 88 percent ( 22 articles), while those discussing the consequences of accrual was around 12 percent ( 3 articles). Compared to between first period and second period, there was an increase in antecedent topics around 66 percent (from 9 articles to 13 articles), while the consequences also increased from 1 article to 2 articles. As for antecedents and consequences, there are no articles as well as others.

Table 3. Classification of topic articles

\begin{tabular}{lcccccc}
\hline \multirow{2}{*}{ Journal } & \multicolumn{2}{c}{$\mathbf{2 0 1 0 - 2 0 1 8}$} & \multicolumn{2}{c}{$\mathbf{2 0 1 0 - 2 0 1 4}$} & \multicolumn{2}{c}{$\mathbf{2 0 1 5 - 1 0 1 8}$} \\
\cline { 2 - 7 } & No & Percentage & No & Percentage & No & Percentage \\
\hline Anteceden & 22 & 0.88 & 9 & 0.9 & 13 & 0.87 \\
Consequence & 3 & 0.12 & 1 & 0.1 & 2 & 0.13 \\
Anteceden dan & 0 & 0 & 0 & 0 & 0 & 0 \\
Consequence & & & & & & 0 \\
Others & 0 & 0 & 0 & 0 & 0 & 0 \\
\hline Total & 25 & & 10 & & 15 & \\
\hline
\end{tabular}

In classifying the antecedent variables, table 4 shows the variables that in this study explaining the application of government accrual accounting in Indonesia amounted to 8 articles or $0.36 \%$ while the factors affecting the development of accrual accounting were around 6 articles or $0.27 \%$. then for the role of accrual accounting 3 articles or $0.13 \%$, and which explains the reliability of accrual accounting developments, there is only one article or 0.04 as well as the development model of accrual accounting is only 1 article or $0.04 \%$.

Table 4. Classification of Antecedent Variables

\begin{tabular}{lcc}
\hline Antecedent Variable & No & Percentage \\
\hline Determinants / Factors & 6 & 0.27 \\
Implementation & 3 & 0.13 \\
Model & 1 & 0.04 \\
Application & 8 & 0.36 \\
Reliability & 1 & 0.04 \\
Role & 3 & 0.13 \\
\hline
\end{tabular}

In table 5, an explanation of the consequence variables in the development of accrual accounting in Indonesia is the quality of financial statements totaling two articles or $0.67 \%$ while the accounting standard amounts to 1 article or $0.33 \%$.

Table 5 Classification of Consequences of Variables

\begin{tabular}{lcc}
\hline \multicolumn{1}{c}{ Consequency Variables } & No & Percentage \\
\hline Quality of Financial Statements & 2 & 0.67 \\
Accrual Based Accounting Standards & 1 & 0.33 \\
\hline
\end{tabular}


The characteristics of a journal based on research topics where JAI, JAK, JAM, JDA, JIAB, JEMA, JIMAT, JA, JEMBA, JAUNEJ, JILIWI, JIIS, JAA, and JEBI are journals which explain or explain antecedent variables totaling 22 articles, while the JMRAAI, JIAB, and $\mathrm{JAB}$ journals are journals which explain the consequence variables which amount to 3 articles.

Table 6. Journal Classification Based on Research Methods

\begin{tabular}{lcccccc}
\hline \multirow{2}{*}{ Journal } & \multicolumn{2}{c}{ 2010-2018 } & \multicolumn{2}{c}{ 2010-2014 } & \multicolumn{2}{c}{ 2015-2018 } \\
\cline { 2 - 7 } & No & Percentage & No & Percentage & No & Percentage \\
\hline Survey & 25 & 100 & 10 & 100 & 15 & 100 \\
Analysis & 0 & & 0 & & 0 & \\
Review & 0 & & 0 & & 0 & \\
\hline Total & 25 & & 10 & & 15 & \\
\hline
\end{tabular}

Table 6 addresses journal classification based on research methods classified into three methods, namely survey, analysis and review of the literature. For eight years for research on the development of accrual accounting using a $100 \%$ survey method ( 25 articles). No other method uses it, this occurs in the first and second periods. When viewed from the first period there were about 10 articles compared to the second period which amounted to 15 articles. In all journals, it can be concluded that the research method in Indonesia when conducting research for the development of accrual accounting mostly uses survey methods. In other words, more use of primary data than secondary data, with data collection techniques using questionnaires, interviews, documents and observations to the place of research objects.

Table 7. Classification of Data Sources

\begin{tabular}{lcc}
\hline Sources of Data & No & Percentage \\
\hline Primary data & 25 & 100 \\
Secondary Data & 0 & 0 \\
\hline
\end{tabular}

\section{Result and Discussion}

The results of the JAI ( 3 articles) provide an overview and empirical evidence of how the level of implementation of accrual accounting in the regional government, the results of the study show that the level of implementation of accrual accounting in the government is still very low, then the staff training factor given to financial staff related to the application of proven accrual accounting has a positive and significant effect on the level of application of accrual accounting. While other factors, namely the level of education of financial staff, the quality of information technology, consultant support, previous experience in running a cash base towards accruals, the leadership education background and the size of the work unit do not significantly influence the level of accrual accounting implementation. Furthermore, the JMRAAI (1 article) with the aim of the research is to examine the effect of standard accounting-based government accounting, accounting information systems, the quality of human feedback, internal control, and organizational commitment affecting the quality of ministry financial reports.

Population of this research is the stakeholders of the financial statements of the National Disaster Management Agency. It employed Likert measurement scale and inferential parametric data analysis. The hypothesis is tested comparatively. The results showed that the 
implementation of Accounting Standards Based on Accrual Accounting had a significant effect on the quality of financial statements, the application of Accounting Information Systems had a significant effect on the quality of financial statements, quality of human resources had a significant effect on the quality of financial statements, internal control had a significant effect on the quality of financial statements, and organizational commitment has a significant influence on the quality of financial statements.

The implementation of Accrual-Based Accounting Standards, Accounting Information Systems, Quality of Human Resources Restoring, Internal Control and Organizational Commitment will increase the quality of financial reports at BNPB. JAK (comprises of 2 Articles) with the aim of getting a more profound benefit in understanding the strategy of implementing accrual accounting in local governments using strength, weakness, opportunities and threats (SWOT) analysis and EFAS and IFAS matrix analysis and obtained shows that internal factors owned by the government are positive while external factors are positive EFAS AND IFAS) whereas according to the SWOT analysis the government gets benefits from the opportunities that exist because it is in quadrant one.

The JAM (two articles) gives an overview of SAP accruals by reviewing the comparison of SAP PP 24/2005 information content based on cash toward accruals and PP 71 the Year 2010 Accrual Basis to unveil the urgency of regional governments (accruals) on accrual-based financial reporting needs. Accrual information report is an urgent need and has a tendency to be difficult to implement as in the case of Sumenep district in East Java, the local government is encountered with the needs of HR, benefit from accrual information and technical difficulties in implementing it. In JIMAT, there is one article, where the study indicate that; 1). Gianyar Regency HR readiness is not ready because it is still in the learning phase to understand the application of accrual-based SAP, 2). Readiness of AIS shows that there is already a special system called the Regional Management Information System (SIMDA) which is used in financial reporting to District Government of Gianyar, and 3). Organizational commitment strongly supports the application of the accrual basis. JIAB Journal (two articles) shows that the results of the research on the variables of HR quality, communication, organizational commitment, and leadership style have a positive effect on the readiness for the application of accrual-based government accounting standards. JA Journal (1 article) the results of this study show that the management of assets/property belonging to the region has not been implemented adequately so as to produce the presentation of asset information that is still not reliable.

Another journal, JIA ( 1 article) shows that the government of the regional public in West Kalimantan has served to understand what is basically based on the accrual accounting system, although it is not fully understood. Government accounting (SAP) based on accruals is a reflection of a formality. This is supported by the existence of government regulations that oblige all local governments including the Manado City government to implement accrualbased SAP. The complexity of financial statements is a major factor in the attitude of Manado City's financial management resistance in the accrual-based SAP implementation. Meanwhile, in terms of organizational culture, Manado City government is required to apply accrual-based government accounting standards. It is better to re-conduct socialization and technical guidance by the central government to the relevant Working Unit of Local Government (SKPD) and the results of the study show that the Tomohon City government in implementing accrual-based SAP has conducted various pieces of training. This is supported by the existence of a government regulation that requires all local governments including the Tomohon City government to implement accrual-based SAP.

The Tomohon City Government should examine the accounting policies and accounting systems more deeply in applying accrual-based SAP. In addition, it is 
necessary to develop the understanding of Tomohon City's financial managers regarding accrual-based SAP, for example, socialization in the form of seminars or discussions with government officials, as well as training related to the accrual-based SAP. JIIS explains the need for serious commitment from all available resources to implement or implement an SAP accrual basis so that the implementation of the SAP accrual basis that is implemented in accordance with the applicable provisions in addition to increasing the competency of human resources needs to be improved. the right and strategic steps in the effort to implement the SAP accrual basis include: The construction of infrastructure in the form of an internet network that can reach all SKPDs and sub-districts needs to be done immediately. Technology transfer needs to be done both from hardware and software so that when damage occurs it can be repaired directly by human resources in the Kepulauan Meranti Regency Government.

Furthermore, JAA (1 article) The results of this study indicate that the level of application of accrual accounting to the government is still very low. In particular, the level of application of accrual accounting is significantly affected by the training of financial staff. However, there is no significant effect of staff education level, quality of information technology, consultant support, experience, leadership education background and work unit size on the level of application of accrual accounting. JEAM (2 articles) The results of this study show that in general District Government Bondowoso was quite ready to implement accrual-based SAP. Existing conditions and obstacles can be overcome by using aggressive strategies to be able to accelerate the readiness of the application of SAP accruals in Bondowoso District Government. And another article also explained that the previous data analysis, the readiness of the Regional Government of Jember Regency indicated by commitment, human resources, infrastructure and information systems can be concluded that the Jember Regency viewed from the parameters of integrity is ready and for HR readiness, information system readiness and infrastructure is a category quite ready.

Constraints in the implementation of Government Regulation No. 71 the Year 2010, regarding Government Accounting Standards (SAP) among others, until now the preparation of Govervement Financial Accounting Report (LKPD) is still done manually (excel) there is no special software, the number of implementing HR in quantity is still insufficient, lack of technical assistance, lack of socialization, existing facilities and infrastructure but still not sufficient. Strategic model for accelerating the implementation of PP No. 71 of 2010 concerning Government Accounting Standards (SAP), among others, Accrual-Based SAP Development in accordance with needs, preparation of Accrual-Based SAP Technical Bulletin in accordance with needs, HR Development in the Field of Government Accounting. While the JILIWI (1 article) describes an accrual basis is an accounting basis in which economic transactions or accounting events are recognized, recorded, and presented in the financial statements at the time of the transaction, regardless of the time cash is received or paid. Accrual basis is used to measure assets, liabilities and fund equity. Thus, the accrual basis is an accounting basis that recognizes the effects of transactions and other events when the transactions and events occur without regard to when cash or cash equivalents are received or paid. Accrual-based accounting is an international best practice in the management of modern finance in accordance with the principles of New Public Management (NPM) that promotes transparency and financial management accountability

\section{Conclusion}


This study analyzes 25 articles in regards with the development of accrual accounting published in accreditation journals in Indonesia. The majority of publishers on accrual accounting are in JAI and other journals. For eight years the most widely used research method is the $100 \%$ survey method or 25 articles. This study is able to provide an overview of the development of accrual accounting in Indonesia so that this study can see the extent to which the implementation of accrual accounting in Indonesia has been carried out by issuing Law No. 71 of 2010, and the results of this study can be used as a reference for further research.

\section{References}

[1] A. Fitriana, A. C. Dewi, and D. Setiawan, "Recent developments in dividend policy: evidence from Indonesia'," J. Keuang. dan Perbank., vol. 22, no. 1, pp. 37-50, 2018.

[2] J. W. Hesford, S.-H. S. Lee, W. A. Van der Stede, and S. M. Young, "Management accounting: a bibliographic study," Handbooks Manag. Account. Res., vol. 1, pp. 3-26, 2006.

[3] S. Lamonisi, "Analisis penerapan standar akuntansi berbasis akrual pada Pemerintah Kota Tomohon," J. EMBA J. Ris. Ekon. Manajemen, Bisnis dan Akunt., vol. 4, no. 1, 2016.

[4] D. Firdaus, D. S. Sayogo, and S. W. Latifah, "Evaluasi Penerapan PP No 71/2010 Tentang Standar Akuntansi Pemrintahan Berbasis Akrual: Studi Kasus di Pemda Nganjuk," J. Account. Invest., vol. 16, no. 1, pp. 25-32, 2015.

[5] N. Ahmar, N. Rokhmania, and A. Samekto, "Model Manajemen Laba Akrual dan Riil Berbasis Implementasi International Financial Reporting Standards," J. Account. Invest., vol. 17, no. 1, pp. 79-92, 2016.

[6] F. Eveline, "Pengaruh SAP Berbasis Akrual, Sistem Informasi Akuntansi, Kualitas SDM, Pengendalian Internal dan Komitmen Organisasi terhadap Kualitas Laporan Keuangan di Badan Nasional Penanggulangan Bencana," Media Ris. Akuntansi, Audit. Inf., vol. 16, no. 1, pp. 1-14, 2017.

[7] E. Herwiyanti, S. Sukirman, and F. S. Aziz, "Analisis Implementasi Akuntansi Berbasis Akrual pada Inspektorat Jenderal Kementerian Keuangan,” J. Akunt. Dan Keuang., vol. 19, no. 1, pp. 13-23, 2017.

[8] M. D. Yafie, "Penerapan Basis Akrual pada Standar Akuntansi Pemerintahan Indonesia," J. Akunt. AKUNESA, vol. 2, no. 1, 2013.

[9] E. F. Tresnawati and A. R. Setiawan, “Ada Apa dengan SAP (AADS) Akrual?,” J. Akunt. Multiparadigma, vol. 4, no. 2, pp. 198-215, 2014.

[10] A. Asfiansyah, "Strategi implementasi akuntansi akrual Pada Pemerintah Daerah (studi kasus pada pemerintah kota 's')," Neo-Bis, vol. 9, no. 1, pp. 1-19, 2015.

[11] K. Priyono, "Keandalan informasi laporan keuangan daerah berbasis akrual: Kajian pengelolaan aset tetap daerah Kabupaten Sampang,” EL MUHASABA J. Akunt., vol. 4, no. 1, 2013.

[12] I. F. Sampel, L. Kalangi, and T. Runtu, "Analisis Kesiapan Pemerintah Kota Manado dalam Penerapan Peraturan Pemerintah Nomor 71 Tahun 2010 Mengenai Standar Akuntansi Basis Akrual,” J. EMBA J. Ris. Ekon. Manajemen, Bisnis dan Akunt., vol. 3, no. 1, 2015.

[13] R. S. Kusuma, "Analisis kesiapan pemerintah dalam menerapkan standar akuntansi pemerintah berbasis akrual," J. Ekon. Manaj. Bisnis dan Akunt., 2013.

[14] T. Setyaningsih, "Studi Eksplorasi Tingkat Pemahaman Aparatur Pemerintah Daerah dan Anggota DPRD terhadap Standar Akuntansi Berbasis Akrual (Kasus di Pemerintah Kota Surakarta)," J. Akunt. dan Bisnis, 2012.

[15] A. Mu'am, "Basis Akrual dalam Akuntansi Pemerintah di Indonesia," J. Lingk. Widyaiswara, vol. 2, no. 1, pp. 38-46, 2015.

[16] S. Surepno, "Kunci Sukses dan Peran Strategis Implementasi Akuntansi Berbasis Akrual," J. Din. Akunt., vol. 7, no. 2, pp. 119-128, 2015.

[17] R. Asmiputri and A. W. Jati, "Analisis Penerapan Standar Akuntansi Pemerintah Berbasis 
Akrual Pada Peraturan Pemerintah No. 71 Tahun 2010 dalam Penyajian Laporan Keuangan Sekretariat UAPPA/BW Kementrian Pertanian Provinsi Nusa Tenggara Barat," J. Reviu Akunt. dan Keuang., vol. 4, no. 2, 2017.

[18] E. Kristiawati, "Faktor-Faktor Yang Mempengaruhi Keberhasilan Penerapan Akuntansi Berbasis Akrual Pada Pemerintahan Daerah Kalimantan Barat," Akuntabilitas, vol. 8, no. 3, pp. 171-190, 2015.

[19] D. Ariyanto, "Faktor-faktor yang Mempengaruhi Penerapan Standar Akuntansi Pemerintahan Berbasis Akrual," E J. Akunt. Univ. Udayana, vol. 13, 2015.

[20] I. A. E. Kiranayanti and N. M. A. Erawati, "Pengaruh Sumber Daya Manusia, Sistem Pengendalian Intern, Pemahaman Basis Akrual Terhadap Kualitas Laporan Keuangan Daerah," E-Jurnal Akunt. Univ. Udayana, vol. 16, no. 2, pp. 1290-1318, 2016.

[21] A. Hariyanto, "Penggunaan Basic Akrual Dalam Pemerintahan Indonesia.," Dharma Ekon., vol. 36, no. 19, 2014.

[22] N. M. A. Widyastuti, S. E. Edy Sujana, I. M. P. Adiputra, and S. H. SE, "Analisis Kesiapan Pemerintah Daerah Dalam Menerapkan Standar Akuntansi Pemerintahan Berbasis Akrual Di Kabupaten Gianyar," JIMAT (Jurnal Ilm. Mhs. Akuntansi) Undiksha, vol. 3, no. 1, 2015.

[23] T. Azman, "Analisis komitmen organisasi, kesiapan sumberdaya manusia, infrastruktur serta sistem informasi dalam menerapkan standar akuntansi pemerintah berbasis akrual," Sorot, vol. 10, no. 1, pp. 131-142, 2015.

[24] M. I. Y. Kusuma and F. Fuad, "Analisis faktor-faktor yang mempengaruhi tingkat penerapan akuntansi akrual pada pemerintah,” Diponegoro J. Account., pp. 525-538, 2013.

[25] M. M. Arif and H. S. Putra, "Aanalisis Kesiapan Pemerintah Daerah dalam Penerapan Standar Akuntansi Pemerintahan Berbasis Akrual (Studi pada Pemerintah Daerah Kabupaten Bondowoso)," J. Akunt. Univ. Jember, vol. 11, no. 2, 2013.

[26] G. A. Adventana and C. H. H. Kurniawan, "Analisis faktor-faktor yang mempengaruhi pemerintah provinsi DIY dalam implementasi SAP berbasis akrual menurut PP No. 71 Tahun 2010," Artik. Publ. Univ. Atma Jaya, Yogyakarta, 2014. 